$e^{3}=$ earth education economics

1st PRME Canada Regional Meeting held on June 12, 2013

MacEwan University, School of Business

Volume 3, Number 2, September 2013

\title{
A Stakeholder's Perspective on the Implications of IFRS and Fair Value Accounting on Valuation of Securities
}

\author{
Glynis Milne* \\ Dr. Eloisa Perez de Toledo* \\ MacEwan University, Canada
}

\begin{abstract}
Due to the complexity of modern financial instruments, accurate valuation can prove difficult even in optimal market conditions. Traditionally International Financial Reporting Standards (IFRS) have allowed securities to be valued based on their historical cost, which results in financial instruments being held on the books at the initial cost paid, until the point at which they are sold. However, this practice may be viewed as problematic when the market value of the financial instrument has not appreciated. Furthermore, market valuation becomes even more difficult to substantiate in illiquid markets, as it may oftentimes be difficult to secure a buyer at any price. Opponents of the historical cost methodology argue that in these circumstances it is unreasonable to allow firms to continue to hold their financial instruments at historical cost, and advocate for a valuation framework that requires the holders of securities to mark their book value to the best estimate of fair market value available. This viewpoint is countered by those who believe that in illiquid markets or markets in crisis, marking to market value is unfair as no functional market exists. In light of the subprime
\end{abstract}


mortgage crisis the new iteration of IFRS requires the use of fair value accounting and marking to market for investment products of all types, with the exception of those held to maturity (bonds). Through a review of current literature, we sought to determine the optimal method for valuation of investment products. Our goal was to determine a reliable and representationally faithful method of valuation that will balance the needs and requirements of all stakeholders and provide transparency in accounting.

\section{Introduction: What is fair value accounting?}

Determining an effective and representationally faithful method of valuation of assets and liabilities has been a longstanding issue in accounting theory. The controversy of methods was first recorded in Kenneth MacNeal's 1939 book Truth in Accounting, when he argued for a market based valuation model for assets and liabilities. Given the increased complexity of investment products and business transactions, the controversy surrounding the relevance, reliability, and representational faithfulness of fair value accounting has continued to grow (Bell \& Griffin, 2012, p. 148). This controversy has given way to a longstanding discussion on the development of an optimal system for valuation.

In order to determine the best course of practice for valuation of financial assets and liabilities (specifically, financial investment instruments), it is important to consider which method will be most representationally faithful, and whether this method enhances the reliability and relevance of financial statements. Generally Accepted Accounting Principles (GAAP) requires that firms classify an investment as "held to maturity," "trading securities," or "available for sale," for the purpose of valuation (Zack, 2009, p. 47). Each of these classifications allows the investment to be valued in a specific manner; Held to maturity investments are carried at the historical, amortized cost, while "held for trading" and "available for sale" securities must be carried at fair value. The important distinction between "held for trading" and "available for sale" securities is that while trading securities have their gains and losses included in earnings, the gains or losses in "available for sale" securities flow through other comprehensive income on the income statement, and are not included in earnings (Zack, 2009, p. 47). International Financial Reporting Standards 13: Fair Value Measurement has made an important departure from the valuation guidelines espoused by private entity GAAP

IFRS 13 dictates that all financial instruments are measured at fair value, with the 
exception of those instruments that are held to maturity (such as bonds), and those equity securities that have no reliable market price (Zack, 2009, pp. 46-47).

The valuation process is aided by a hierarchy of three levels, which helps determine whether an investment should be valued at historical cost, or fair value. This hierarchy examines whether there is a verifiable input (such as a quoted stock price), underpinning the valuation. Observable inputs such as current quoted prices on the market allow an instrument to receive a classification of Level I, whereas completely unverifiable inputs necessitate Level 3 classifications. Those instruments with less reliable inputs, but that can be somewhat substantiated or extrapolated on the market, are classified as Level 2 (KPMG, 2011, P. 29). This classification system (as well as much of IFRS 13) requires significant use of professional judgment, especially when performing valuation in depressed markets, or in the instance of forced sales (KPMG, 2011, P. 32). In this case, accounting professionals should seek information to determine whether they should change valuation methods, or use a hybrid of methods to determine the most accurate assessment of value. A debate on the use of fair value accounting in such markets will be presented later. It is important to consider the implications of stating an asset at fair value, when the market dictates that the item is presently non-saleable, or has suffered a temporary loss in value so significant that it could not be liquidated at a price close to its intrinsic value. An asset's intrinsic value is subjective, and may be calculated based on its ability to generate revenue, or the sum of the value of it components. Intrinsic value does not consider what an asset could be sold for in the market. In illiquid markets, it is possible that the market value (the price an asset can be sold for in the market) of an investment product can fall significantly below its intrinsic value.

As world economies have become increasingly interconnected, the adoption of IFRS and fair value accounting has accelerated across countries (Jeanjean \& Stolowy, 2008, p.5). This adoption has been met with varying levels of acceptance from the numerous stakeholders who use, work with, or prepare financial statements. Although the viewpoints on this issue are varied, they can be generalized so as to aid in an understanding of the diverse perspectives on the adoption of IFRS. The differing viewpoints on fair value accounting from the perspectives of users of financial statements, standards setters, financial institutions, preparers of financial statements, and auditors will be examined. This examination will form the basis of presenting the recommendation for a reliable, relevant, and representationally faithful means of accounting for investment products using the framework of IFRS 13. 


\section{Users and non-institutional investors}

An internationally unified and consistently applied set of financial reporting standards can potentially hold significant value for individual investors and users of financial statements (Ball, 2006, p.6). IFRS 13 can provide users of financial statements with increased understandability, accuracy and reliability of statements, and improve their decision-making capacity. IFRS also offers individual investors a high degree of standardization of financial statement reporting, which garners lower costs, and higher market efficiency (p. 6). Additionally, these non-institutional investors and individual users may find that the improved financial statements produced through the use of international financial reporting standards leads to decreased risk and truer valuation of investment products (p.11). It is important to note that the implementation of IFRS is bound inextricably to the concept of fair value accounting, and that this coupling is likely to increase in strength as IFRS becomes more widely accepted (p. 17).

One of the primary advantages for investors, to the use of fair value accounting in IFRS 13, is the improved accuracy of financial information. As non-institutional investors and individual users oftentimes lack the projection and investigative capabilities of larger investors, fair value accounting gives them an accurate representation of the true value of the firm's financial health at the present date. This allows them more equality with large-scale institutional investors (Ball, 2006, p.11). Additionally, fair value accounting offers all investors an accurate valuation of how financial instruments are affected by the state of the market at the current time (PWC, 2008, p.2). This knowledge gives investors the power to make more informed decisions regarding their investments, and gives them a clear picture of their investments performance within current market conditions. Historical cost method can hide current performance from investors, especially those that have less market acumen. Curtis and Lewis found that when firms use the historical cost method, a significant difference exists between the value of a firm's assets on their books, and the actual market valuation of the assets. As such, they observed an upward bias with respect to the actual rate of return (2011, p.5). The existence of these biases in historical cost accounting, and the lack of transparency offered by this method's valuation practices means that investors will likely prefer the more accurate valuation method of fair value accounting.

\section{Standards setters}

Standards setters such as the Financial Accounting Standards Board (FASB), and the Securities Exchange Commission (SEC) have mandates to aid in the protection of 
investors through overseeing the production of reliable and accurate financial information by nongovernmental organizations (FASB, 2013). These standards setters are committed to promoting a consistent method of financial statement creation, which helps investors make sound investment decisions (FASB, 2013). As such, standards setters have endeavored to promote the use of IFRS 13 and fair value accounting as a means to providing transparent, relevant and reliable information to investors. The Securities Exchange Commission states that its primary mission is "protect investors, maintain fair, orderly, and efficient markets, and facilitate capital formation" (SEC, 2013). Therefore, the SEC has publicly stated their support for the implementation of IFRS 13 (IFRS, 2013). The SEC believes that fair value accounting offers the most reliable means of valuation, and as such, offers individual investors assurance that this is currently the most optimal method of valuation. Given the impartial viewpoint of these organizations, they do not have a vested interest in endorsing a valuation method that is harmful to investors.

\section{Financial institutions}

Financial institutions have expressed concern over the implementation of fair value accounting. These institutions argue that due to the interconnectedness of financial markets, fair value accounting could negatively impact financial stability of the market in its entirety (Shaffer, 2012, p.14). Many financial institutions believe that in the case of illiquid markets, a drop in the value of securities (caused by marking the securities to market) could cause individual firms value to drop. In turn, this value drop could create contagion in the market and has the power to collapse or severely damage the normal functioning of the market (pp.25-26). Organizations such as the American Bankers Association have lobbied against the use of fair value accounting in illiquid markets. However, the definition of illiquidity is subjective and difficult to quantify. If these organizations wish to advance their arguments against fair value methodology, financial institutions should make determinations on objective measurements for what constitutes an illiquid market.

Financial institutions argue that fair value accounting exacerbates financial downturn by signaling distress to the market (Shaffer, 2012, p.9). These institutions oftentimes advocate for a mixed measurement technique that offers flexibility in valuation by allowing historical cost to be used in illiquid markets, and when an asset is being held for long term. Additionally, the mixed measurement technique does not respond to short-term changes in the market, which proponents of this method argue can falsely signal market downturn and cause contagion.

ECJ Volume 3, No. 2, 2013: $\mathrm{e}^{3}=$ earth education economics 


\section{Preparers}

Those firms, who prepare financial statements for use by investors, have a complex relationship with fair value accounting. They need to balance firm profitability with providing comparable, accurate financial statements. Firms will argue that fair value accounting depresses the value of their assets below what they believe is accurate, and as such, argue against marking securities to market. It is particularly interesting to note that directly preceding the adoption of IFRS in Europe between 2002 and 2005 the markets enjoyed an overall increase in equity valuations (Armstrong, Barth, Jagolinzer, \& Riedl 2009, p.30). This may demonstrate that the firms who prepare these statements can benefit from accurate application of fair value accounting. However, these incremental increases in value are overshadowed by more significant issues that firms who prepare financial statements have with fair value accounting. These issues include inaccurate or indeterminable valuation in illiquid markets, problems with the creation of earnings volatility, and problems with the uniform application of fair value accounting principles.

Although the aim of fair value accounting to provide the most accurate representation of valuation of investment products is noble, preparers of financial statements are quick to bring attention to its shortcomings. As outlined in the April 2008 edition of Point of View, fair value accounting has trouble addressing valuation in illiquid markets, and its process of marking to market mean that its use can cause earnings volatility as the valuation of assets and liabilities are in constant flux with market changes (PWC, 2008, p. 2).

When assigning a fair value to financial instruments in an illiquid market, the use of models and professional judgment are crucial. However, it is arguable that in these situations an assignment of value merely fulfills rules and does not serve to increase the reliability or relevance of financial information (Chasan, 2008, para. 5). Companies have argued that when markets are illiquid, the use of fair value accounting (which dictates that instruments be marked to market at statement dates) is unrealistic and can have serious long-term ramifications for the health of the firm (PWC, 2008, p.1). In turn, they argue that inaccurate valuations by way of fair valuation can artificially diminish the value of a firm (PWC, 2008, p.1). Incorrectly decreasing the value of a firm can place an otherwise viable company in danger of insolvency, when their financial position was not otherwise in danger. These firms believe that by marking down securities during times of severe market depression, these assets will be represented below their intrinsic value. The American Bankers Association argues that in illiquid markets, holders of financial instruments recognize that their assets are undervalued, and thus cannot and will not 
attempt to sell them on the market. In turn, this causes a slowing or seizing of the markets, which contributes to illiquidity (ABA, 2012, para. 7). Preparers are troubled by the practice of assigning value to an asset that could not currently be sold on the market. They are uncomfortable with the practice of using any method other than true market value (i.e. models and professional judgment) to assess an asset that is supposed to be valued using market prices. It is argued that when utilizing fair value accounting models and professional judgment to assign a value to assets in illiquid markets, there is no way of gaining an accurate valuation. Therefore, the viewpoint of many financial institutions is that as the markets are seized and illiquid, it is impossible to gain an accurate representation of fair value, because fair market value does not exist at this point.

Firms (and specifically those who hold financial instruments on their balance sheets as a regular part of operations) have been critical of the use of fair value accounting due to its ability to imbue earning volatility that is not caused by management or general operations. Although fair value accounting is a powerful tool for providing accurate and timely information of the financial state of a company, it is also responsible for the presentation of a great deal of undesirable earnings volatility (PWC, 2008, p.2). As securities must be marked to market on a regular basis, their valuation is represented in a constant state of fluctuation on the books of the financial statement preparers and can thus contribute to volatility (Laux \& Leuz, 2009, p.31). Earnings volatility is undesirable from the perspective of management and investors, so any accounting standard that creates it is troubling (Venkatachalam, 2000, p.204). Such volatility can oftentimes be indicative of risky investments or corporate mismanagement, which further explains the apprehension of firms towards standards that promote volatility in earnings. In an empirical study by Ronnie Barnes at the London Business School, earnings volatility showed a significant impact on the market value of a firm. This study revealed that volatile earnings are often accompanied by decreased share values, and demonstrated the importance of judicious consideration of accounting standards usage (2001. p. 21). These empirical findings support the view by many firms that fair value accounting can negatively impact their business valuation and the overall health of their firm. Any earnings volatility has the power to impact the robustness of the share price, and decrease shareholder returns. As such, many of the public, non-governmental firms that would be impacted by mandatory fair value accounting are strong advocates against its widespread implementation.

The increased use of professional judgment in the application of fair value accounting and IFRS 13 is especially concerning as it may result in inequalities in application of accounting standards (Zack, 2009, p. 13). As institutions rely upon 
accurate valuation of their financial assets for their continued sustainability, they are weary of a method that has thus far been difficult to apply uniformly. Specifically, the issue of misclassifying securities poses major risks to organizations. Institutions are interested in assuring that their competitors are all subject to the same classification standards, as the misclassification of one firms securities can place them at an advantage above their competitors (Zack, 2009, p.53). IFRS 13 had mandated the use of fair value accounting for securities, but many firms do not feel that they have done an adequate job protecting their interests by assuring uniform application of standards. In illiquid markets especially, it is important that firms are assured the most accurate and uniform practices of valuation of their securities. IFRS 13 has struggled to provide a way of giving firms assurance of consistently applied, reliable and accurate valuation in both stable and unstable markets. In order to gain support from those institutions that hold securities on their balance sheets, standards setters must endeavor to provide a more concrete method for the application of fair valuation practices and should provide more diligent monitoring and allow for less professional judgment in the application of financial accounting reporting standards.

Without a clear and defensible value of a financial instrument in the market, the fair valuation method fails to provide any increased assurance of relevance, reliability, or representational faithfulness beyond that offered by the historical cost method. Additionally, the argument that fair value accounting can be detrimental to the overall health of a firm causes discomfort among many companies. Given the issues surrounding fair valuation, it can be difficult for firms to justify the use of fair value accounting in place of the use of historical cost valuation.

\section{Auditors}

The main duty of an auditor is to verify that financial statements are representational and accurate, so as to avoid material misstatement (Smieliauskas \& Bewley, 2013, pp. 8-9). Given this aim, auditors are charged with verifying valuations provided by clients, by ascertaining additional valuations for securities. These valuations can be problematic to establish under the framework of fair value accounting. Fair value accounting presents complications to auditors including difficulties with the measurement of assets, the need for extensive professional judgment, and disclosure issues when valuation is questionable (IAASB, 2008, p.4).

In order to verify an asset's value when using fair value methods, other professionals may need to be contracted to assist with determining an accurate 
assessment. These professionals may be required to use assessments of the market and their own judgment or in the case of illiquid markets they may use valuation models (Barnes, 2001, p.8). The highly subjective nature of this process makes it difficult for auditors to replicate and verify (IFAC, 2008, p.7). This further complicates the valuation process beyond that which existed when historical cost was employed. Fair valuation makes an auditor's job of verification much more complex, as it dictates that he or she be able to issue assurance that the assets are valued correctly. This involves making assessments on the classification of assets, as well as their valuation (IFAC, 2009, p.4). In the case of historical cost method, auditors were responsible for determining that the asset was being held at the correct cost and was not inflated or deflated from its historical cost. This process was far less complex and the valuation figures were much easier to verify.

As IFRS 13 and fair value accounting allow for a significant amount of flexibility in professional judgment upon initial valuation, which can be problematic for an auditor. This can present issues because the auditor may not have access to the professional who initially made the valuation. In such situations, the auditor may be required to make assumptions regarding the valuation (IFAC, 2008, p.6). This process inherently poses risks to the reliability of auditor's assertions. However, it is likely that these issues will diminish as auditors and professionals become more cognizant of the new requirements for valuation.

Issues with disclosure also arise due to fair valuation methods. Auditors must assess the risk of misstatement, and disclose areas in which they have concerns regarding the accuracy of a client's assertions (Smieliauskas \& Bewley, 2013, p.170). Because of the issues surrounding the reliability of information surrounding valuations, it is possible that it will be more unlikely that auditors will be able to offer unqualified audit reports, even to companies that have proceeded with careful and ethical valuation of their assets (IAASB, 2008, p.7). However, this should not be presented as an unresolvable issue. Given sufficient time and experience, auditors and clients should be able to build a system of more easily verifiable fair valuation methods, as both parties gain more experience with the requirements imposed upon them by IFRS 13.

Auditors operating under fair value assumptions have a great number of additional challenges in assuring the reliability and accuracy of the valuation (IAASB, 2008, p.5). However, these challenges do not make fair valuation impossible for auditors. Fair value accounting in its present iteration may increase the amount of time an auditor will spend verifying client assets, but this is not an indication that this valuation method is flawed 
(IAASB, 2008, p.3). Once auditors have gained more experience with the requirements of fair value, and clients have grown accustomed to the level of verifiability that they should demand for their valuations, these stakeholders will be able to work within the methodology together, to produce financial statements that are accurate, reliable and verifiable.

\section{Discussion and Recommendations}

Despite controversies surrounding the use of IFRS 13's fair value accounting methodology, it is our opinion that fair valuation remains the best method for assessing the value of financial instruments. This valuation method offers the most reliable and accurate representation of a firm's value in current market conditions. It gives investors a reliable assessment of the firm's performance and is not impacted by erroneous information on an assets previous valuation. However, IFRS 13 does not offer a perfect version of fair value accounting, and as such it should be amended in order to yield more reliable, relevant and representationally faithful financial statements and valuations with less reliance on professional judgment.

Assessments that use fair valuation can cause contagion and severely damage the market are flawed; they fail to accept the basic premise of market forces. There is no need to conceal the reality of market conditions in order to bolster firm valuation. By using historical cost valuations in depressed markets, institutions are in essence intervening in the market by attempting to improve performance by concealing market information. It seems improbable that given the use of correct write-downs and accurate valuations, there would be any way that marking securities to market would cripple or even wound the international financial markets. Furthermore, it is the authors' opinion that fair valuation does not impact market performance of a firm, but rather accurately represents it in financial statements. Through the use of fair value accounting, investors will be better equipped to make sound investment decisions given accurate information.

The goal of accurate valuation for investment products is one that cannot be accomplished through the implementation of IFRS 13 and fair value accounting alone. As argued by Jeanjean and Stolowy, standards setters should also take other factors into account, when striving towards a common system that supports reliable, relevant, and representationally faithful valuation. These factors include attempting to ensure uniform application of standards (including legal sanctions and enforcement), and more coordinated competition rules across different markets (2008, p.16). Implementation of fair value accounting through IFRS does not in and of itself assure that the standards

ECJ Volume 3, No. 2, 2013: $\mathrm{e}^{3}=$ earth education economics 
will be applied uniformly or correctly across, and within markets. The current status of the implementation of IFRS 13 and fair value accounting (along with asset classification) is one that is focused more on gaining support for the methodology and less on assuring that it is applied consistently and correctly. In order for fair value accounting to offer better accuracy of valuation and financial statements, proponents of the method should endeavor to create a better system of monitoring and sanctioning its implementation. The stock market regulators of each IFRS member nation (such as the Securities Exchange Commission in the United States) could administer this system of observation and sanctions. The presence of an overseer would encourage firms to strictly adhere to the rules set out by the IFRS regarding classification and valuation of securities. Auditors would also play a large role in assuring that fair value accounting was uniformly applied. Similarly to how they presently report fraud to appropriate authorities, auditors could become responsible for reporting incorrect application of fair value accounting methods. The presence of monitoring and sanctions for fair value accounting application would serve to encourage all firms to implement this practice correctly, and would increase investor confidence in the market overall.

IFRS 13 allows for a significant amount of professional judgment with respect to the application and usage of accounting financial reporting standards (Zack, 2009. P. 13). This decrease in explicit guidance (with respect to GAAP and previous iterations of IFRS) can cause problems with consistency when applying classifications and assigning valuations. In order to assure that the advantages of fair value accounting principles are realized, standards setters must commit more time and lobbying efforts to standardizing application of the methodology across and within markets. Until the role of professional judgment is removed or decreased in IFRS, it will be difficult to achieve complete consensus among professionals with respect to the application of fair value accounting. In order to remedy this, it is the authors' recommendation that the influence of

professional judgment in future versions of IFRS, be decreased. This professional judgment allows for inconsistencies across users and harms the ability of fair value accounting to yield reliable, relevant and representationally faithful valuations and financial statements.

\section{Conclusion}

The adoption of fair value accounting and IFRS holds many advantages for businesses. Given the already widespread acceptance of this methodology, it will allow businesses to present their valuation in such a way that it is directly comparable with competitors (IFRS, 2013, para. 5). This can hold the advantage of increasing consumer 
confidence in the reliability and accuracy of a firm's valuation, and consequently improve their share price and market value. As stakeholders become more versed in the requirements of fair valuation, the method will become easier to implement. The increased usage of fair value accounting will serve to improve transparency and reliability of valuation and financial statements across markets. Coupled with improvements to the current iteration of IFRS, fair value accounting will provide users of financial statements the most accurate and reliable information. Operating within the global marketplace, fair value accounting has the power to improve the markets' ability to operate without intervention, by enhancing the quality of information and helping investors to become better, more informed participants in the free market.

* Author: Glynis Milne is a recent graduate of the Bachelor of Commerce program (Accounting maj.) at MacEwan University. Prior to beginning her accounting studies she earned a Bachelor of Science (Human Ecology) from the University of Alberta. Glynis' interests in accounting include financial standards, risk analysis, and valuation for securities. She will begin her public accounting career this fall, where she will be pursuing her Chartered Account designation.

* Author/Advisor: Dr. Eloisa Perez, de Toledo is an assistant professor in the School of Business, Bachelor of Commerce at MacEwan University.

\section{References}

American Bankers Association. (2013). Fair value and mark to market accounting. Retrieved from http://www.aba.com/Issues/Index/Pages/Issues FairValue.aspx.

Armstrong, C., Barth, M., Jagolinzer, A., \& Riedl, E. (2009). Market Reaction to the adoption of IFRS in Europe. Accounting Review, Forthcoming.

Ball, R. (2006). International Financial Reporting Standards (IFRS): pros and cons for investors. Accounting and business research, 36(sup1), 5-27.

Barnes, R. (2002). Earnings volatility and market valuation: An empirical investigation. LBS Accounting Subject Area Working Paper No. ACCT019.

Chasan, Emily (2008). Is fair value accounting really fair? Retrieved from http:/ /www.reuters.com/article/2008/02/26/us-column-liftingidUSN1546484120080226. 
Curtis, A., \& Lewis, M. (2011). The comparability of accounting rates of return under historical cost accounting. Available at SSRN 1660671.

Deloitte LLP. (2007). International financial reporting standards for U.S. companies: Implications of an accelerating global trend. Retrieved from http://www.deloitte.com/assets/DcomUnitedStates/Local\%20Assets/Documents/us assurance international financial r eporting std $\% 20$ 030108(1).pdf.

Fahnestock, R. T., \& Bostwick, E. D. (2011). An analysis of the fair value controversy. Proceedings of ASBBS at Las Vegas, 18(1), 910-921.

Financial Accounting Standards Board. (2013). Facts about FASB. Retrieved from http://www.fasb.org/jsp/FASB/Page/SectionPage\&cid=1176154526495.

IACPA. (2013) International financial reporting standards. Retrieved from http://www.ifrs.com/updates/aicpa/ifrs faq.html\#q4.

International Auditing and Assurance Standards Board (2008). Staff audit practice alert. Retrieved from http://www.ifac.org/sites/default/files/downloads/staff audit practice alert.pdf2 $\underline{008 .}$

International Auditing and Assurance Standards Board (2009). Emerging practice issues regarding the use of external confirmations in audit of financial statements.

Retrieved from http://www.ifac.org/sites/default/files/downloads/iaasb staff audit practice aler t external confirmations.pdf.

IFRS Foundation. (2013). About the IFRS foundation and the IASB. Retrieved from http://www.ifrs.org/The-organisation/Pages/IFRS-Foundation-and-the-IASB.aspx.

IFRS Foundation (2012). IFRS 13 fair value measurement. Retrieved from http://www.ifrs.org/IFRSs/Documents/IFRS13.pdf.

Jeanjean, T., \& Stolowy, H. (2008). Do accounting standards matter? An exploratory analysis of earnings management before and after IFRS adoption. Journal of accounting and public policy, 27(6), 480-494.

KPMG LLP. (2010) IFRS compared to Canadian GAAP: an overview. (3 ${ }^{\text {rd }}$ ed.) 2010. Retrieved from http://www.kpmg.com/Ca/en/IssuesAndInsights/ArticlesPublications/Document s/IFRS IFRSGAAPComparisonThirdEd2009-10.pdf. 
Laux, C., \& Leuz, C. (2009). The crisis of fair-value accounting: Making sense of the recent debate. Accounting, organizations and society, 34(6), 826-834.

Laux, C., \& Leuz, C. (2009). Did fair-value accounting contribute to the financial crisis? (No. w15515). National Bureau of Economic Research.

PWC. (2008). Fair value accounting: Is it an appropriate measure of value for today's financial instruments? Retrieved from http://www.pwc.com/en US/us/point-of view/assets/pwc pointofview fairvalue.pdf

Shaffer, S. (2012) Evaluating the impact of fair value accounting on financial institutions: Implications for accounting standards setting and bank supervision. Retrieved from http://www.bos.frb.org/bankinfo/qau/wp/2012/qau1201.htm

Securities Exchange Commission. (2013). The Investor's advocate:How the SEC protects investors, maintains market integrity, and facilitates capital formation. Retrieved from http://www.sec.gov/about/whatwedo.shtml

Smieliauskas, W., Robertson, J. C., \& Bewley, K. (2010). Auditing : An international approach / Wally J. Smieliauskas, Kathryn Bewley. Toronto : McGraw-Hill Ryerson, c 2013.

Venkatachalam, M. (2000). Discussion of corporate disclosure practices, institutional investors, and stock return volatility. Journal of Accounting Research, 38, 203-207.

Zack, G. M. (2009). Fair value accounting fraud: New global risks and detection techniques / Gerard M. Zack. Hoboken, N.J. : John Wiley \& Sons, c 2009. 